Ann. Zootech., 1980, 29, no h. s., 73-84.

\title{
Net requirements for maintenance as dependent on weight, feeding level, sex and genotype, estimated from balance trials
}

\author{
A.J.H. VAN ES \\ Institute for Livestock Fecding and Nutrition Research \\ 2 Runderweg, Postbox 160,8200 AD Lelystad (The Netherlands)
}

\begin{abstract}
In the introduction attention is paid to the ratio of maintenance feed to total feed in growing animals which is seldom less than 0.4 This shows the need for an accurate estimate of maintenance requirements.

The various methods to derive or predict this requirement are critically discussed. Attention is paid to protein turnover rate, work of growth and the physical activity of growing animals; an attempt is made to develop a model which takes account of these aspects. Finally a survey is given of most estimates of maintenance requirements of growing cattle and comments are made regarding the reliability of these estimates.
\end{abstract}

\section{Résumé}

Estimation des besoins énergétiques nets d'entretien à partir des résultats de bilcn: variations en fonction du poids, du niveau d'alimentation, du sexe et du genotype

Dans l'introduction, l'auteur attire l'attention sur l'importance des besoins d'entretien des animaux en croissance, qui représentent rarement moins de $40 \mathrm{p} .100$ des besoins totaux; ce qui montre l'intérêt d'une estimation précise des besoins d'entretien.

Ensuite, l'auteur présente et discute les différentes méthodes utilisées pour déduire ou prévoir les besoins d'entretien. Il souligne l'imıportance de l'intensité du renouvellement des protéines, du «travail de croissance » et de l'activité physique chez les animaux en croissance et propose un modèle mathématique tenant compte de ces facteurs. Enfin, l'auteur fait une revue de la plupart des estimations des besoins d'entretien des bovins en croissance et discute leur validité. 


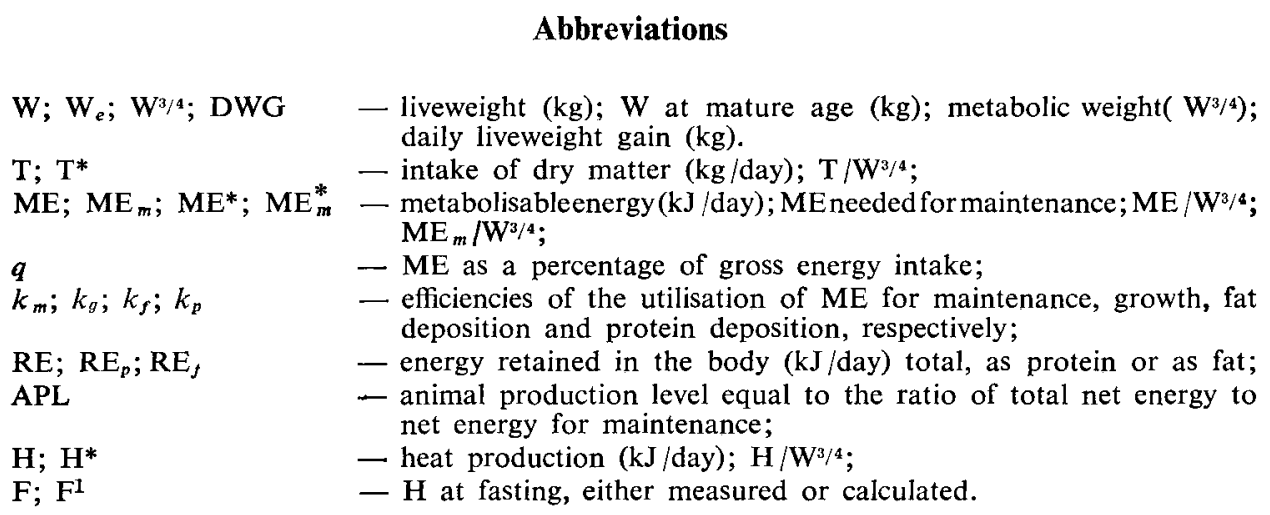

\section{Introduction}

Maintenance metabolism of growing animals, even of those growing very rapidly, makes up a large part of total metabolism. Chickens, young pigs and veal calves seldom use less than one third of the energy of their ration to maintain themselves, usually maintenance requires more, especially at low rates of daily gain (NiJKamp et al., 1973 ; Verstegen, 1971 ; THorbek, 1975 ; VAN ES et al., 1967). In growing, ruminating cattle and sheep maintenance metabolism is seldom less than 40 per cent of total metabolism and usually more (GEAY et al., 1973 ; Schulz et al., 1974). At a higher weight during growth the feed intake potential per unit of metabolic weight decreases slowly. The same is the case with the percentage of the energy retained as protein which may be as high as 65 per cent at a low weight, 50 per cent in young ruminating ruminants decreasing to 10 - 15 per cent near maturity (BöHmE et al., 1976 ; VAN ES et al., 1967 ; Blaxter et al., 1966 ; Joshi, 1972 ; Graham, 1970). For both reasons maintenance energy- and $\mathrm{N}$ - metabolisms become a more important part of total metabolism at higher body weights and of course the more so at low rates of gain.

Thus the large part of the feed used for maintenance purposes easily explains the interest in having good estimates of this part of total metabolism. In addition, from a good understanding of the physiology of maintenance metabolism some means might be derived which lowers the amount of food required for it.

In this respect there are two subjects which need special attention : the physical activity and the rate of $\mathrm{N}$ turnover of the young animals. Young animals often show a somewhat higher physical activity than older ones, they are also more easily stressed (WENK and VAN ES, 1976). Physiological studies suggest that $\mathrm{N}$ turnover during rapid growth has an increased rate (MILLwARD et al., 1976 ; VAN ES, 1978 ; WEBSTER, 1979). Both phenomena increase total energy costs, for physical activity this is immediately apparent, for the rate of $\mathrm{N}$ turnover it should be considered that each time that a gram of existing body protein is hydrolysed to amino acids the resynthesis of this protein from the free amino acids resulting from its hydrolysis requires energy (ATP). 


\section{The measurement of maintenance requirements of the growing animal}

Many ways exist to determine maintenance requirements fot energy (VAN ES, 1972 ; HENCKEL, 1976).

The animals can be fasted for a number of days at the end of which estimates of maintenance metabolism are derived from heat production and urinary energy loss (Method A).

The animals can also be fed approximate maintenance rations ; from their average daily liveweight gain (Method B1) or energy balance (Method B2) it can be computed how much of the ration is needed for maintenance only.

Finally regression methods can be used to derive maintenance estimates from measurements of liveweight gain or energy balance at two or more levels of intake at all liveweights followed by extrapolation to zero production (Method C).

Such regressions are often also applied to data from growing animals fed ad libitum or nearly so. The feeding level of such animals decreases with body weight, thus theoretically the condition for regression and for extrapolation to zero energy retention, i.e. having data from two or more feeding levels, is fulfilled. However, there is a bias, the data at high and at moderate feeding levels relate to young animals and old animals, respectively, so maintenance estimates thus obtained should be looked at with some caution.

In growing animals Method A fails because the animals may show an abnormal behaviour due to fasting, since these young animals are easily stressed.

Even in mature animals too high fasting values are obtained when the fasting trial is not preceded by a period during which a maintenance ration only is fed. Such a period on maintenance feeding prior to fasting might reduce the stress of fasting to the young animal. However, it might also allow metabolism more time to adapt to the low feeding level so that a fasting value is obtained which does not tell much about the animal's maintenance requirements during rapid or moderate growth.

A similar objection holds true also for Method B. Both Hoffmann et al., (1977) and WEBSTER (1978) consider these two methods of doubtful value for the prediction of maintenance requirements of rapidly growing animals. Instead they prefer to derive such estimates from measurements made during rapid or moderate rates of growth. This leads to the various regression methods of Method C, usually based either on model C1 or model C2 :

$$
\begin{aligned}
& \text { production }=a \times \text { intake }+b \\
& \text { intake }
\end{aligned}
$$

In these models intake may be expressed in $\mathrm{kg}$ feed per day. This would result in a great residual variation when applied to results of trials in which diets with different digestibilities or metabolisabilities are used.

For this reason intake is usually expressed as intake of metabolisable energy (ME). Very often, unfortunately, $\mathrm{ME}$ is calculated rather than measured during the growth of the animals. The calculation uses chemical composition or digested nutrients measured with the animals themselves at maintenance or at production level or with sheep at maintenance level, and methane losses are often estimated rather than measured. Production is generally expressed as daily energy gain, occasionally as daily liveweight gain. In the first case either the balance or the 
comparative slaughter technique is used. The two techniques do not always give the same results. Energy balances slightly, and nitrogen balances often considerably overestimate actual balances, moreover their nonsystematical errors are fairly high as all errors made in measuring input and output accumulate in the balance. In the slaughter technique errors are easily increased when the animal's energy and $\mathbf{N}$ content is determined indirectly, e.g. by density, by analysis of ribcuts and when only a small initial slaughter group is used in trials of a short length. This means that both the intake and the production data may have errors of which the size can be considerable depending on the kind of methods used and on the care with which the measurements are performed.

Production is often partitioned in daily protein and daily fat gain, either expressed in grams or in kilojoules (C3) :

$$
\mathrm{ME}=e^{\prime} \times \mathrm{P}+f^{\prime} \times \mathrm{F}+g \text { and } \mathrm{ME}=e \mathrm{RE}_{p}+f \mathrm{RE}_{f}+g
$$

in which $\mathrm{P}$ and $\mathrm{F}$ are daily protein and fat gain in grams and $\mathrm{RE}_{p}$ and $\mathrm{RE}_{f}$ are daily retained energies as protein and as fat.

In all models the constants $b, d$ and $g$ give an estimate of maintenance.

To account for differences in body weight within the set of data used for regression instead of these constants the terms $h \mathrm{~W}^{\mathrm{P}} . i \mathrm{~W}^{\mathrm{P}}$ and $j \mathrm{~W}^{\mathrm{P}}$ are introduced. In other words, it is assumed that the model needs another independent variable, $\mathrm{W}^{\mathrm{P}}$, but does go through the origin so that a constant term is not needed :

$$
\begin{aligned}
& \mathrm{RE}=a \times \mathrm{ME}+h \mathrm{~W}^{\mathbf{P}} \\
& \mathrm{ME}=c \times \mathrm{RE}+i \mathrm{~W}^{\mathbf{P}} \\
& \mathrm{ME}=e \times \mathrm{RE}_{p}+f \times \mathrm{RE}_{f}+j \mathrm{~W}^{\mathrm{P}}
\end{aligned}
$$

It will be clear that $b$ and $h$ will have a negative value. The exponent $\mathrm{p}$ should have a value which best relates maintenance requirement to body weight. Most experimental work with mature or nearly mature animals suggests $p$ to be close to $3 / 4$ (writing the exponent in this way is preferred ; writing it as 0.75 suggests a too high degree of precision). Even with mature animals fed at the maintenance level it is difficult to obtain a precise estimate of p. For a high accuracy the range of $\mathrm{W}$ should be great which for the same breed is an impossible condition. A greater range of $\mathrm{W}$ in mature animals of different breeds is possible but in that case the estimate of $p$ may be biased by species differences in maintenance requirement. Large variation in weight is easy to obtain in young, growing animals but here we do not have reliable estimates of maintenance requirements. However, we could try to find the best value of $p$ using the models C4-6 in a set of data from growing animals of the same breed showing great variation in liveweight. The best value could be assumed to be the value which gives the lowest residual variation. In all such regression studies internal correlations invalidate the results : with increase of body weight ad libitum or restrictedly fed animals show a decrease of intake and of gain per metabolic weight, moreover the composition of their gain shows an increasing fat to protein ratio and their physical activity decreases. These biases are especially great when only ad libitum feeding is applied as mentioned above. This means that in all our models C4-6 the data of one independent variable are correlated with the data of the other independent variable(s). The result is that the values of $p$, but also of $a, b, e, f, h, i$ and $j$, resulting from the regression computations are biased. 
To reduce the effect of these bias factors on the result VAN Es et al. (1967) worked with two feeding levels in veal calves, nearly ad libitum and some 20 per cent less so that the data on body weight and energy deposition were not so closely correlated. Pullar and Webster (1977) also used more than one feeding level but in addition selected normal (lean) and genetically obese individuals from the same litter of Zucker rats. At the same ME intake level and body weight the lean rats deposited more protein and less fat than the obese rats, thus the correlation between fat to protein deposition ratio and body weight was diminished. The regression model used was: $\mathrm{ME}=k+b \mathrm{RE}_{p}+c \mathrm{RE}_{f}$, in which $k$ was kept constant only for the same genotype at the same weight. Thus, as in the earlier models the ME costs of deposition of protein and fat were assumed to be constant per $\mathrm{kJ}$ deposited, however maintenance requirements $(k)$ were assumed to be similar only within genotype within liveweight but regardless of feeding level.

Some research workers use another approach in which heat production $(\mathrm{H})$ rather than intake is used. According to Garretr (1970) plotting $\log \left(\mathrm{H}^{*}\right)$ against $\mathrm{ME}^{*}$ gives a straight line (the asterisk stands for $/ \mathrm{W}^{3 / 4}$ ). Where $\mathrm{ME}^{*}$ on this line equals $\mathrm{H}^{*}$ energy retention is zero, so the $\mathrm{ME}^{*}$ value at this point is the quantity needed for maintenance. The assumption regarding this curvilinear relation of $\mathrm{H}^{*}$ and $\mathrm{ME}^{*}$ may be doubted. Most energy balance experiments with mature cattle or sheep fed the same feed at different levels above maintenance and with lactating cows (VAN Es, 1975) show a linear relationship provided $\mathrm{H}^{*}$ and $\mathrm{ME}^{*}$ apply to the same feeding level and the same diet. In many experiments by GARRETT and co-workers, however, ME was not measured at the actual feeding level but calculated from digestion trials at maintenance. Extrapolation of $\mathrm{H}^{*}$ to zero $\mathrm{ME}^{*}$ to obtain data on fasting metabolism was done. The reliability of such fasting data may be doubted as only results of trials at or above maintenance were used.

GARRETT also estimated $\mathrm{ME}_{m}^{*}$ by extrapolating in the plot of $\mathrm{RE}^{*}$ against $\mathrm{T}^{*}$ (intake of dry matter $/ \mathrm{W}^{3}$ ), $\mathrm{RE}^{*}$ to 0 and converting $\mathrm{T}$ into $\mathrm{ME}$.

WEBSTER (1978), much interested in the possible effect of growth on the size of maintenance, tried to exclude all feed effects influencing the results obtained. So he had to work with estimates of basal metabolism, e.g. fasting heat production, during actual growth. He doubted the value of the measured fasting heat production for this purpose and preferred the calculated fasting heat production $\mathrm{F}^{1}$.

Energy retention and ME intake were measured repeatedly during the growth period of cattle at moderate and rapid rates of liveweight gain. $F^{1}$ was computed with the following equation $-\mathrm{GE}=$ gross energy intake -

$$
\mathrm{F}^{1}=k_{m}\left(q \mathrm{GE}-\mathrm{RE} / k_{f}\right)
$$

The values $q, k_{m}$ and $k_{f}$ were from experiments with mature sheep fed the same diet or only $q$ was measured and $k_{m}$ and $k_{f}$ were predicted using the ARC (1965) or BlaXTeR (1973) equations. In this way both the effect of protein deposition, probably lowering the actual efficiency of the utilisation of the ME for growth $k_{g}$ of the animal below $k_{f}$, any other effects of " work of growth " and increased physical activity would show up in the $F^{1}$ values. In other words, $F^{1}$ values should not be considered to be true maintenance estimates of growing animals, they are only calculated figures useful to detect a possible higher total heat production caused by growth. Scaled per metabolic weight the greatest differences between the $F^{1}$ of growing animals and the $F$ of mature animals will of course be seen in the very young, very rapidly growing animals. WEBSTER proposed as a first approach that the difference between $F$ and $F^{1}$, the "work of growth", might be related to 
$\frac{\mathrm{W}}{\mathrm{W}_{e}} \ln \frac{\mathrm{W}}{\mathrm{W}_{e}}$, in which $\mathrm{W}_{e}$ is the weight of the animal at maturity. This term is the first differential of the Gompertz equation which might describe the relationship between "work of growth" and stage of maturity W/W $\mathrm{W}_{e}$. A disadvantage of the term is that for a $W_{e}$ of $750 \mathrm{~kg}$ it is fairly constant over the range of 200 to $600 \mathrm{~kg}$ and falls off sharply thereafter.

Hoffmann et al. (1977) and Tyrrell and MoE (1979) proceeded in a slightly different way. Using model C4 they predicted a value for $k_{g}$, a value which was applied in the same material to derive $\mathrm{ME}_{m}^{*}$ :

$$
\mathrm{ME}_{m}^{*}=\mathrm{ME}^{*}-\mathrm{RE}^{*} / k_{g}
$$

Since $k_{g}$ was obtained from growing rather than mature animals, it may be lower than the $k_{f}$ used by WEBSTER in C7. Thus, still higher values of $\mathrm{ME}_{m}^{*}$, better called $\mathrm{ME}^{* 1}$, might have been found with the $\mathrm{k}_{g}\left(=k_{j}\right)$ of mature animals. As in WeBsTER's approach the purpose of the calculation of such $\mathrm{ME}_{m}^{* 1}$ values is only to see if they differ from ME* values found in mature animals of the same breed fed similar diets. Such possible differences might be due to protein turnover, physical activity and other "work of growth".

In view of our present unfortunately still limited knowledge of protein turnover and physical activity we might extend model $\mathrm{C} 6$ by two terms. First $\mathrm{k}_{p}$ might be assumed to be related to the relative rate of protein deposition, i.e. to $\mathrm{RE}_{p} / \mathrm{W}$. Future work on $\mathrm{N}$ deposition might show whether this very simple prediction of rate of protein turnover or the main part of the "work of growth" suffices. Secondly part of the physical activity of the animal might be related to youth, i.e. decreasing with increasing degree of maturity $\mathrm{W}-\mathrm{W}_{e}\left(\mathrm{~W}_{e}\right.$ values as will be understood are to differ from breed to breed).

This leads to model $\mathrm{C} 9$ :

$$
\mathrm{ME}=\left(a+b \mathrm{RE}_{p} / \mathrm{W}\right) \mathrm{RE}_{p}+c \mathrm{RE}_{f}+\left\{d+e\left(\mathrm{~W}-\mathrm{W}_{e}\right)\right\} \mathrm{W}^{\mathrm{p}}
$$

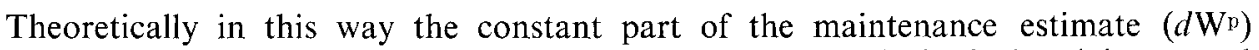
will be almost free of the influence of protein turnover and physical activity caused by youth while $b$ and $e$ indicate the size of these influences. The whole term $\left\{d+e\left(\mathrm{~W}-\mathrm{W}_{e}\right)\right\} \mathrm{W}^{\mathrm{P}}$ could be considered as the total maintenance of a young animal consisting of a constant part and a part varying with age.

To my knowledge model $\mathrm{C} 9$ has not been used so far. It shares the drawback with model $\mathrm{C} 6$ (and also $\mathrm{C} 5$ and $\mathrm{C} 2$ ) that independent variables are used which have a low precision $\left(\mathrm{RE}, \mathrm{RE}_{p} . \mathrm{RE}_{f}\right)$ and this increases the error of the regression coefficients. On the other hand model C9 has the great advantage that its constants can indeed be considered to be constants; the regression constants of model C6 very likely change with body weight and rate of gain. Unfortunately the information given in the publications on experiments with growing animals is too incomplete for a successful application of model C9. Moreover, if the data used are only from ad libitum fed animals the regression will not differentiate between $\mathrm{RE}_{p} / \mathrm{W}$ and $\mathrm{W}-\mathrm{W}_{e}$, making the values of $b$ and $e$ unprecise.

These considerations lead to the disappointing conclusion that there appears to be no completely correct method for deriving the total maintenance requirement of growing animals $\left(\left\{d+e\left(\mathrm{~W}-\mathrm{W}_{e}\right)\right\} \mathrm{W}^{\mathrm{P}}\right)$ at present $\left(^{1}\right)$. All estimates of mainte-

(1) In pigs at various feeding levels WALACH-JANIAK et al. (1979) assumed an increase of maintenance due to protein deposition equal to $\left(e^{k \cdot \mathrm{RE}_{p}}-1\right)$, an interesting hypothesis. However, it did not improve the fit of the model to the data, although suggesting a higher value of $k$, thus a greater influence of protein deposition on maintenance, in boars than in castrated males. This model gives a higher increase of additional maintenance due to protein deposition at higher body weight. 
nance published so far should be interpreted with caution as not only may the regression models used be criticised severely but also the data of the variables of the regressions may have large errors. At present we cannot do much better than to reconsider these maintenance estimates in view of the method and models used to derive them, and applying corrections to them. where that seems advisable in the light of the theory underlying model C9.

It will be clear that the greatest doubt on the precision of the maintenance estimate concerns the very young rapidly growing animal. It probably has a high rate of $\mathrm{N}$ turnover and is physically rather active. So in cattle and sheep lack of precision will be greatest in the pre-ruminant period. There-after protein energy deposition, except for late-maturing breeds at high feeding level, is usually 30 per cent or less of total energy deposition. Thus $\mathrm{N}$ turnover rate probably will not be very high, moreover at this age the animals are more quiet than in their early youth. Feeding them rations near maintenance rather than ad libitum does not change their behaviour very much. So we might conclude that for these cattle maintenance estimates obtained with methods $\mathrm{B}$ or $\mathrm{C}$ will not be too imprecise and will become more reliable with advancing liveweight. Of course, they apply to the situation in which the measurements have been made i.e. animals kept tethered, for those kept in a feedlot, for animals at pasture, etc. For the exception made above, i.e. for late-maturing bulls fed intensively the errors will be greater; so method $\mathrm{C}$ is to be prefered.

\section{Maintenance estimates for cattle obtained so far}

The less recent literature has been reviewed by VAN Es (1972). The conclusion reached was that for very young growing cattle, e.g. vaal calves under $100 \mathrm{~kg}$, the maintenance requirement was probably somewhat higher than that of older, but still growing, animals and than that of mature animals. Above $150 \mathrm{~kg}$ maintenance requirements per metabolic weight appear to stabilise at values between 500 and $400 \mathrm{~kJ} \mathrm{ME*}$. The figures obtained with Method A (fasting) were considered to be not very reliable. With regard to values obtained by regression model $\mathrm{C} 4$ for veal calves, close to $460 \mathrm{~kJ} \mathrm{ME}{ }_{m}$, it was stated that comparisons of these values with those for older ruminating animals should be based on net energy rather than ME requirements. Probably some $560 \mathrm{~kJ}$ ME of rations for ruminating cattle contain the same maintenance net energy as $460 \mathrm{~kJ}$ ME of a milk replacer ration for veal calves. It demonstrates the so calculated higher net energy requirement for maintenance of pre-ruminant cattle under $150 \mathrm{~kg}$. However, these high values might be apparent rather than true, so model C9 might better be used to obtain maintenance values. So far this has not been done but it would probably lower the $\mathrm{ME}_{m}^{*}$ estimate.

The variation of the values $500-400 \mathrm{~kJ} \mathrm{ME} / \mathrm{W}^{3 / 4}$ for ruminating cattle was said to be due to measurement errors, differences in behaviour and in adaptation to housing and treatment during the experiments as well as to individual variation. Seen in the light of our present knowledge, part of the higher maintenance values of the younger cattle may have been due to a too low estimate of the costs of protein deposition.

More recent work gave results which in general were in agreement with the conclusions reached above. VERMOREL et al. (1974) in male Normand veal calves of $90-240 \mathrm{~kg}$, fed milk replacer at one high feeding level only and found a value of $402 \mathrm{~kJ} \mathrm{ME}_{m}^{*}$ when applying model C4. KIRCHGESSNER et al. (1976) using the 
comparative slaughter technique for German Braunvieh veal calves of $55-155 \mathrm{~kg}$ calculated $\mathrm{ME}_{m}^{*}$ values of 431 using model $\mathrm{C} 5$ and of 498 using model $\mathrm{C} 4$. In experıments with male Friesian calves fed mainly milk replacer ad libitum or 25 per cent less, Vermorel et al. (1979) found a value of $452 \mathrm{~kJ}$ at an age of 5 weeks, using model C. Hoffmann et al. (1977) obtained for male German Black and White calves below $75 \mathrm{~kg}$, fed a similar diet, a value of 452 , calculated by decreasing the $\mathrm{ME}$ intake by 0.72 times the energy retention. WEBSTER et al. (1976) found in male British Friesian veal calves, fed milk replacer at 3 feeding levels for periods of 2-3 weeks in the weight range of $90-210 \mathrm{~kg}$ by regressing $\mathrm{RE}^{*}$ on $\mathrm{ME}^{*}$ a $\mathrm{ME}_{m}^{*}$ of $675 \mathrm{~kJ}$. At the highest level the calves gained $1.4 \mathrm{~kg} /$ day. They were kept separately and could not see or smell each other which might partially explain this very high value. In the experiments of VAN Es and of those described above the aninials could at least smell or see one other calf.

For all these values of pre-ruminant calves it holds true that for comparison with the $\mathrm{ME}_{m}^{*}$ values of $420-500 \mathrm{~kJ}$ of older ruminating cattle they have to be increased by some 20 per cent. Then most values become above or near 500 , 1.e. fairly high, probably due to the higher physical activity of these calves and due to an underestimation of the costs of protein deposition or "work of growth" at the higher feeding levels.

THORBEK and HeNCKel (1976) found with Method $\mathrm{C}$ for growing male Red Darish and Holstein-Friesian calves of $100-250 \mathrm{~kg}$ fed a diet of concentrates and hay, values for $\mathrm{ME}_{m}^{*}$ of $519 \mathrm{~kJ}$ at a high and of 423 at a lower feeding level; Method $\mathrm{B}$ gave a value of 431 .

When the calves of VERMOREL et al. (1979) became older and milk replacer was gradually replaced by solid feed, maintenance values decreased from 10 to 34 weeks in 3 groups $(414 \rightarrow 385 \mathrm{~kJ}-$ ad libitum $-; 356 \rightarrow 318 \mathrm{~kJ}-3 / 4 \times$ ad libitum - and $414 \rightarrow 385 \mathrm{~kJ}-$ ad libitum -$)$ and increased in one $(356 \rightarrow 385 \mathrm{~kJ}-$ $3 / 4 \times$ ad libitum -) when to calculate these values a $k_{g}$ was used obtained within groups at a given age $\left(10,23\right.$ and 34 weeks) by regressing $\mathrm{RE}^{*}$ on $\mathrm{ME}^{*}$. Final weights were about $310 \mathrm{~kg}$ for the ad libitum groups and about $265 \mathrm{~kg}$ for the others. HoFFMANN et al. (1977) assumed that the utilisation of the ME for growth of their bull calves at weights of $70-250 \mathrm{~kg}$, receiving more and more solid feed, decreased linearly from 72 to 56 per cent and by using these $k_{f}$-values obtained maintenance values of 506 between 75 and $100 \mathrm{~kg}, 540$ between 100 and $225 \mathrm{~kg}$ and 510 between 225 and $250 \mathrm{~kg}$.

VERMOREL et al. (1979) found $k_{g}$ values of 51-46 per cent, i.e. much lower than the values of $72 \rightarrow 56$ per cent used by HoffMANN et al. (1977); however the $\mathrm{ME}_{m}^{*}$ estimates of VERMOREL $e t$ al, were much lower. The rations of these two studies hardly differed as to metabolisability. The $k_{g}$ values of HofFmanN et al. were estimates, taking into account a $k_{g}$ value of 58 per cent obtained with model $\mathrm{C} 4$ for all results of their bulls, most of which (77 per cent) weighed more than $250 \mathrm{~kg}$ during the measurements. Maybe lower estimates of $k_{g}$ than $72 \rightarrow 56$ per cent should have been used in view of the higher relative rate of protein deposition below versus above $250 \mathrm{~kg}$. The fact that in the calculations of VERMOREL et al. $k_{g}$ was calculated within narrow age-ranges, might explain their low $k_{g}$ values, accounting more correctly for the protein deposition costs.

GARRETT (1970) did not detect significant differences in $\mathrm{ME}_{m}^{*}$ between Hereford steers and heifers weighing 195-520 and 195-430 kg respectively, the estimates being $456 \pm 62$ and $464 \pm 59$ for the regression of $\log \mathrm{H}^{*}$ on $\mathrm{ME}^{*}$ and $515 \pm 29$ and $506 \pm 25$ for the regression of RE* and $T^{*}$. Although the same high-concentrate ration was fed both ad libitum and near maintenance, lack of information makes 
correction of the maintenance estimate in view of present knowledge on costs of protein deposition and physical activity impossible.

Also in a study of most of his comparative slaughter trials GARRETT (1979) found nearly the same values for his calculated F-values for steers and heifers. The study did not contain information on $\mathrm{ME}_{m}^{*}$-estimates.

HofFMANN et al. (1977) derived from all their results with growing bulls in the range of $50-500 \mathrm{~kg} \mathrm{a} k_{\mathrm{g}}$-value of 58 per cent by regressing $\mathrm{EB}^{*}$ on $\mathrm{ME}^{*}$. Using a $\mathrm{k}_{g}$-value of 56 per cent for the animals above $250 \mathrm{~kg}$ gave maintenance values of 417,460 and $414 \mathrm{~kJ}$ for the weights of $250-300,300-325$ and above $325 \mathrm{~kg}$ respectively.

GEAY et al. (1979) using the comparative slaughter technique while assessing final body energy from 11 th ribcut and fifth quarter's fat, studied Charolais $\times$ Salers bulls and heifers fed ad libitum and restrictedly. Maintenance values obtained by plotting $\mathrm{EB}^{*}$ against $\mathrm{ME}^{*}$ were close to $450 \mathrm{~kJ}$, slightly more for the bulls than for the heifers.

WeBSTER (1979) calculated predicted basal metabolism $\mathrm{F}^{1}$ (discussed above) for Friesian and Aberdeen Angus $\times$ Friesian steers, Hereford $\times$ Friesian steers and Hereford $\times$ Friesian bulls, as being $440 \mathrm{~W}^{3 / 4}, 676 \mathrm{~W}^{0.65}$ and $788 \mathrm{~W}^{\mathbf{0 . 6 5}} \mathrm{kJ}$, respectively. The latter two estimates, if converted to $W^{3 / 4}$, become for $W=250 \mathrm{~kg}$ $389 \mathrm{~W}^{3 / 4}$ and $454 \mathrm{~W}^{3 / 4}$ and for $\mathrm{W}=450 \mathrm{~kg} 367 \mathrm{~W}^{3 / 4}$ and $428 \mathrm{~W}^{3 / 4}$. For comparison purposes these values are divided by the $k_{m}$ values used to calculate $\mathrm{F}^{1}$; so we obtain the following values of predicted $\mathrm{ME}_{m}^{* 1}: 587(\mathrm{~F}+\mathrm{A} \times \mathrm{F}$ steers); for $250 \mathrm{~kg} 519$ and for $450 \mathrm{~kg} 489(\mathrm{H} \times \mathrm{F}$ steers); for $250 \mathrm{~kg} 605$ and for $450 \mathrm{~kg} 571(\mathrm{H} \times \mathrm{F}$ bulls). These rather high values, especially those of the bulls growing on average $1.3 \mathrm{~kg}$ per day (versus 0.9 for the steers), will partly be due to the high (mature) values of $k_{f}$ used. Thus it is probable that actual $\mathrm{ME}_{m}^{*}$ values were lower but there is insufficient information in the publications to calculate their size e.g. by using model C9.

TyrRell and MoE (1979) fed 8 Hereford heifers during their growth from 220 to $430 \mathrm{~kg}$ at ad libitum and near maintenance feeding levels. Using a common $\mathrm{k}_{f}$ derived from the whole material they estimated average maintenance values of 515 and 456 for the two rations used. There was a tendency toward a decline with increasing age; the values at the high feeding levels were higher than at the maintenance level. For these high feeding levels the value of $k_{f}$ used might have been too high in view of the greater rate of protein deposition so that their $\mathrm{ME}_{m}^{*}$ estimates became too high.

Table 1 summarises the more recent results; comments are made to express the author's view that some estimates of $\mathrm{ME}_{m}$ are incorrect in view of the method of computation used. The values of WEBSTER et al. and WEBSTER are high compared to all other estimates. Only part of the discrepancy can be explained. Taking into account the more efficient utilisation of the $\mathrm{ME}$ of the diets of pre-ruminant calves, their $\mathrm{ME}_{m}$ estimates are high, most probably because they are not completely free from protein deposition costs or "work of growth" and furthermore perhaps, because of their higher physical activity. The estimates in the weight range of $70-250 \mathrm{~kg}$ at high feeding level might also include some protein deposition costs or "work of growth". This also applies, to a progressively lesser extent, to the cattle above $250 \mathrm{~kg}$. A tentative estimate of $\mathrm{ME}_{m}^{*}$, not or hardly containing protein deposition or "work of growth" costs, might be $400 \mathrm{~kJ}$ both for pre-ruminant calves and also for older cattle; it should be understood that the $400 \mathrm{~kJ}$ ME of the calves is equal to some $500 \mathrm{~kJ}$ ME for older cattle. 


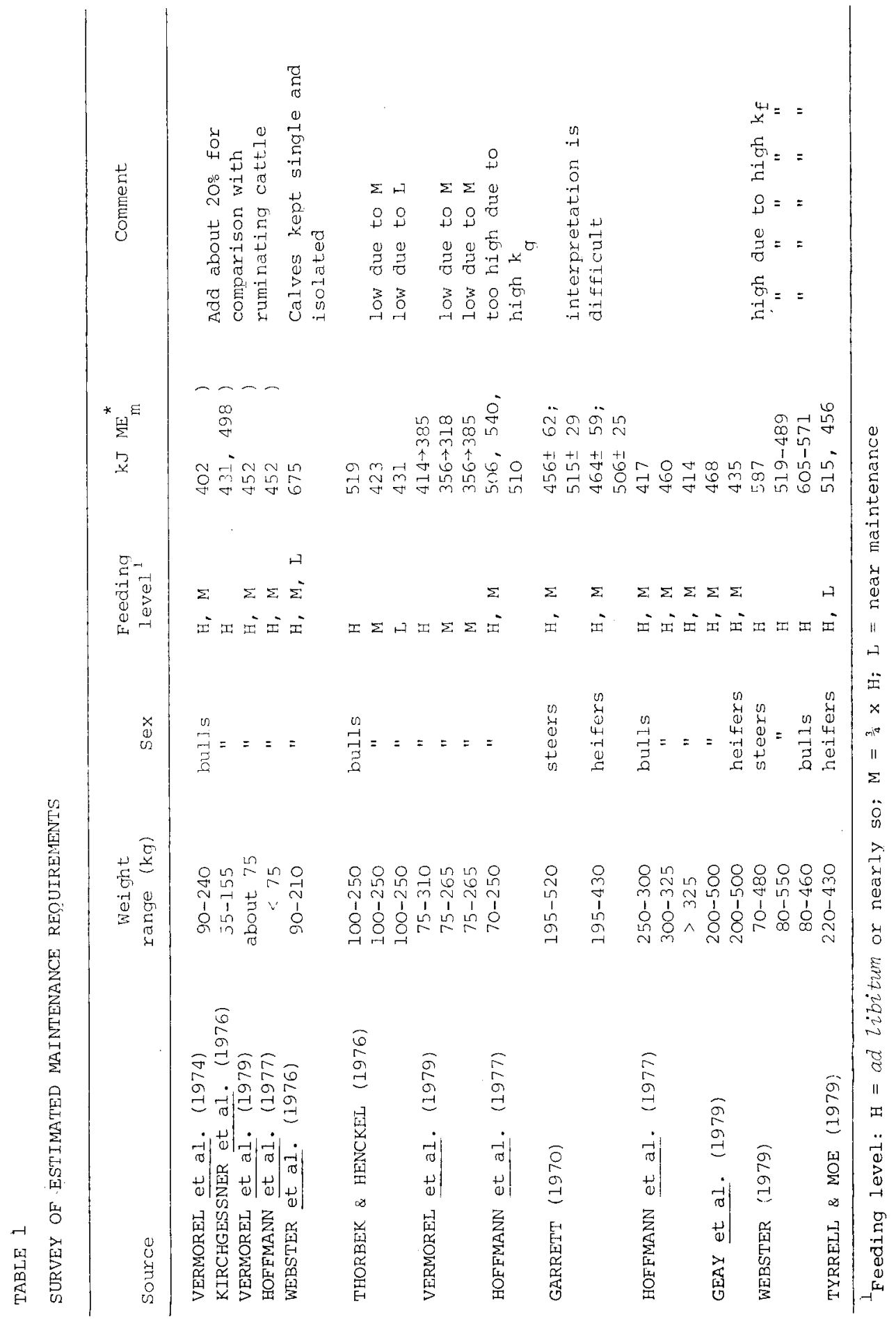




\section{References}

ARC (Agricultural Research COUNCIL), 1965. The nutrient requirements of farm livestock. Ruminants, No. 2 ; ARC, London.

Blaxter K.L., Clapperton J.L., Wainman F.W, 1966. Utilisation of the energy and protein of the same diet by cattle of different ages. J. Agric. Sci., Camb. 67, p. 67-75.

Blaxter K.L., 1973. Metabolisable energy and feeding systems for ruminants. In : Proc. Nutr. Conf. Feed Manufacturers, No. 7, Nottingham. H. Swan and E. LEwIS, eds., Butterworth, London.

Böhme H., Gadeken D., Oslage H.J., 1976. Untersuchungen über Höhe und Verlauf des Stickstoff und Energieansatz frühentwöhnter Ferkel. Proc. 7th Symp. Energy Metab. EAAP, Vichy, p. 165-168.

Es A.J.H. Van, Nijkamp H.J., Weerden E.J. Van, Hellemond K.K. VAN, $1967 . \quad$ Energy, carbon and nitrogen balance experiments with veal calves. Proc. 4th Symp. Energy Metab., EAAP, Warsaw, p. 197-201.

Es A.J.H. VAN, 1972. Maintenance. In : Handbuch der Tierernährung. II. Eds. W. LENkEIT, K. Breirem, Parey, Hamburg, p. 1-54.

Es A.J.H. VAN, 1975. Feed evaluation for dairy cows. Livest. Prod. Sci. 2, p. 95-107.

Es A.J.H. VAN, 1978. Nutritional efficiency of protein and fat deposition. In : Patterns of Growth and Development in cattle. Eds. H. DE Boer, J. MarTin, Nijhoff, Den Haag, p. 361-382.

Es A.J.H. VAN, 1979. Energy costs of protein deposition. Proc. 29th Easter School, Sutton Bonington (In press.).

GarretT W.N., 1970. The influence of sex on the energy requirements of cattle for maintenance and growth. Proc. 5th Symp. Energy Metab., EAAP, Vitznau, p. 101-104.

GARRETT W.N., 1979. Energy utilisation by growing cattle as determined in seventy-two comparative slaughter experiments. Proc. 8th Symp. Energy Metab., Cambridge 1979.

Geay Y., Robelin J., JaRRIge R., 1973. Variations des quantités d'énergie, de protéines et de lipides fixées dans la carcasse par les jeunes taureaux à l'engrais. Proc. 6th Symp. Energy Metab., EAAP, Hohenheim, p. 139-142.

Geay Y., Robelin J., Vermorel M., 1979. Influence of the metabolisable energy content of the diet on the energy utilisation for growth in bulls and heifers. 8th Symp. Energy Metab., EAAP, Cambridge.

Graham N. McC, 1970. Growth in sheep. Proc. 5th Symp. Energy Metab., Vitznau, p. 105 108.

Henckel S., 1976. Statistical methods for estimation of maintenance requirement and efficiencies in animal production during growth. Proc. 7 th Symp. Energy Metab., Vichy, p. 145-148.

Hoffmann L., Jentsch W., Schiemann R., 1977. Die Verwertung der Futterenergie durch wachsende Bullen. 4. Mitt. Der Energie und Proteinbedarf wachsender Bullen. Arch Tieren., 27 , p. 545-562.

JosHI D.C., 1972. Evaluation of energy in early and late cut hay with growing bulls. Scient. reports Agric. Univ. Norway, 51, 36, p. 1-24.

Kirchgessner M., Müller H.L., Meesse K.L., 1976. Energy retention and utilisation by the veal calf. Proc. 7th Symp. Energy Metab., Vichy, p. 201-204.

Millward D.J., Garlick P.J., James W.P.T., Sender P.M., WaTerlow J.C., 1976. Protein turnover. In : Protein metabolism and nutrition. D.J.A. Cole et al. eds., Butterworth, London, p. 49-69.

NiJkamp H.J., Es A.J.H. Van, Huisman E.A., 1973, Retention of nitrogen, fat, ash, carbon and energy in growing chickens and carp. Proc. 6th Symp. Energy Metab., EAAP, Hohenheim, p. 277-280.

Pullar J.D., Webster A.J.F., 1977. The energy cost of fat and protein deposition in the rat. Br. J. Nutr., 37, p. 355-363.

Schulz E., Oslage H.J., Daenicke R., 1974. Untersuchungen über die Zusammensetzung der Körpersubstanz sowie den Stoff- und Energieansatz bei wachsenden Mastbullen. Zs. Tierphysiol. Tierernähr. u. Futtermittelk., Beiheft 4, 70 pp.

Thorbek G., 1975. Studies on energy metabolism in growing pigs. II. 424. Beretn. Statens Husdyrbrugsfors $\phi g$, p. 107-126. 
ThorbeK G., Henckel S., 1976. Studies on energy requirement for maintenance in farm animals. Proc. 7th Symp. Energy Metab., EAAP, Vichy, p. 117-120.

Tyrrell H.F., Moe P.W., 1979. Energetics of growth in cattle. Proc. 8th Symp. Energy Metab., EAAP, Cambridge.

Vermorel M., Bouvier J.C., Thivend P., Toullec R., 1974. Utilisation énergétique des aliments d'allaitement par le veau préruminant à l'engrais à différents poids. Proc. 6th Symp. Energy Metab., EAAP, Hohenheim, p. 143-146.

Vermorel M., Bouvier J.C., GeAY Y., 1979. Energy utilisation in growing calves : effects of age, milk intake and feeding level. Proc. 8th Symp. Energy Metab., EAAP, Cambridge.

VERSTEGEN M.W.A., 1971. Influence of environmental temperature on energy metabolism of growing pigs housed individually and in groups. Med. Landbouwhogeschool Wageningen 71-2, pp. 115. Thesis, Wageningen, 1971.

Walach-Janiak M., Kotarbinska M., Kielanowski J., 1979. Energy metabolism in growing boars. Proc. 8th Symp. Energy Metab., EAAP, Cambridge.

Webster A.J.F., Gordon J.C., SMITH J.S., 1976. Energy exchanges of veal calves in relation to body weight, food intake and air temperature. Anim. Prod., 23, p. 35-42.

Webster A.J.F., 1978. Prediction of the energy requirements for growth in beef cattle. Wld. Rev. Nutr. Diet., 30, p. 189-226.

Webster A.J.F., 1979. The energetic efficiency of growth. 30th Ann. Meeting, EAAP, Harrogate. GN 4.2, 8 pp.

WENK C., Es A.J.H. VAN, 1976. Energy metabolism of growing chickens as related to their physical activity. Proc. 7th Symp. Energy Metab., EAAP, Vichy, p. 189-192. 